\title{
Growth and Productivity of Poplar Species in Southeastern Kazakhstan
}

\author{
Dani Sarsekova
}

Department of Forest Resources and Forestry, Faculty of Agronomy, S.Seifullin Kazakh Agro Technical University, Kazakhstan

Copyright $(\mathcal{C} 2015$ by authors, all rights reserved. Authors agree that this article remains permanently open access under the terms of the Creative Commons Attribution License 4.0 International License

\begin{abstract}
A small area of forestation and an acute shortage of timber are reasons to seek ways to improve productivity and the rational use of forests in the territory of Kazakhstan. A deficit in timber can be compensated, to some extent, by planting stands of fast-growing plantation species, including top and hybrid Populus spp, which are commonly referred to as "poplar". There is an increased interest in poplar, globally, due to its organic traits and the economic value it provides, including: rapid growth and ability to produce wood that is technically suitable for cutting within 20 years of planting; a source of suitable timber for use in most industries; the ability to grow in soils that are not generally suitable for agricultural use; a potential source of timber for widespread use in screening, landscape and recreational plantings; the ability of most popular species and hybrids to asexually propagate. There has been extensive planting of poplar trees in Kazakhstan, especially in the south and south-east. Poplar trees have been planted in populated areas, along roads and in forest stands. However, these plantings are unsuitable as a source of timber for commercial or ornamental purposes. Hence, there is a need to establish plantations of poplar for timber supply in Kazakhstan. The most common types of poplar in this country are the deltoid, Algerian, and Bolle, which were used in the extensive greenery planting of southeastern Kazakhstan. The main factors ensuring high productivity of poplar plantations are the soil conditions of fertility, good aeration and adequate moisture. Results of this study indicate that the greatest height increase occurs in these trees between the age of 5 and 10 years, and for trunk diameter, between the age of 4 and 9 years. After this age, the growth rate gradual declines, with a sharp drop in the rate noticeable between years 14 and 16. Additionally, results of this study show the high productivity of poplar plantations, in plot sizes 2.5 to 3 $\mathrm{m}$ by 1.5 to $2 \mathrm{~m}$, with $2000-3000$ trees per hectare. This compares with the production of timber mass from stands of $5000-7000$ trunks per hectare, which leads to rapid growth of trees in height, but an earlier growth reduction in diameter.
\end{abstract}

Keywords Hybrid Poplar, Poplar Species, High-yield Plantations, Linear and Capacity Plantings, Growth, Productivity

\section{Introduction}

Kazakhstan is a sparsely vegetated state. According to the forest fund, in 2014 Kazakhstan's forest cover was only $4.6 \%$ of the entire country. Furthermore, the country's forest resources continue to dwindle through forest fires and illegal logging, which further increases the demand for timber.

The lack of wood is particularly acute in sparsely populated areas and in the southern regions of Kazakhstan, which specialize in crops, vegetables, fruits and grape cultivation that require a large amount of timber for making collection boxes under fruit trees and vineyards, packing cases, packing chips, sawdust, and other items. These needs could be provided by plantation timber from fast-growing tree species, including top and hybrid poplar species.

However, the right assortment of tree types, and adequate forms of compliance and technology are needed to create high-yield poplar plantations within a fairly short time interval to meet these needs.

\section{Study Objectives and Methods}

Annual surveys were conducted on both rows and large plantations of poplars, grown in varying soil types in the climatic zone of Southeastern Kazakhstan.

At the same time, plantations of specific poplars and plantations of hybrid poplars, of foreign and local selection, were examined.

After a preliminary examination of plantations, the most typical areas for situating the study plots were selected. Trial plots were laid in such a way that each contained at least 100 trees. Depending on the placement of the trees in the plantation, the size of plots ranged from 0.03 to 0.12 hectares.

Each test area was described by the period of planting, the row width, the distance between rows, row direction, agricultural cultivation, and tree survival at the time of the survey.

In addition, a description of the soil profile was produced, 
including the depth to groundwater. Any infestations of pest or plant diseases were noted, as were natural deficits of branches. For each plot, the tree mass was calculated using the tree diameter at $2 \mathrm{~cm}$ from the base, diameter at breast height, and the tree trunk height. Diameters were measured using a dimensional fork, and height by way of a hypsometer. The data and description of plots were recorded in the field.

Based on continuous calculation of average heights and diameters of the plantation, sample trees were selected and felled, one by one, for individual samplings. Trunk cross-sections were cut for enumerating annual layers and determining diameter measurements. Cross-sections of the trunk were examined at the butt at breast height, then at 3.6, 5.6, 7.6, $9.6 \mathrm{~m}$, and so on, along the trunk. Studying the course of growth, and defining timber stocks, was performed according to the standard procedures, and adopted for forestry inventory (Anuchin). Overall, there were three test areas.

\section{Research Results}

Poplar trees have high natural plasticity and great potential. Poplar wood is soft and white and elastic, characterized by the absence of odors, colorants and resins and is widely used in construction, furniture industry, container, match, plywood, pulp and paper production. In addition, poplar wood can be used as fuel, fodder and medicinal raw materials [1].

Poplar in Kazakhstan is one of the main species of field-protective forestation d landscaping. [2] It is planted along the irrigation ditches, canals, roads, along rivers and reservoirs as well as it is used in the reclamation of mine dumps, etc. $[3,4,5]$.

The main reasons for the development of poplar industry in Kazakhstan is a high demand for wood and the need for large volumes of work on recreational, landscaping and protective wood cultivation.

Poplar species. In Southeastern Kazakhstan, poplar species are widely grown. These species include the deltoid (Populus deltoides Marsh), the black pyramid (Populus pyramidalis Rozies), the Bolle (Populus bolleana Lauche), the Algerian (Populus thevestina Dode), the leafy (Populus densa Kom.), the black (Populus niqra L.), the much-less-cultivated Bachofen poplar (Populus bachofenii Wierzb), the white (Populus alba L.), the balsamic (Populus balsamifera L.), the laurel-leaved (Populus laurifolia Ledeb), the red excitatory (Populus vernirubens Henry), and the

\section{Chinese (Populus Simonii Carr).}

The Alamo, Algerian, and Bolle species of poplar are most popular in practical terms, for wood plantations. Below are the results of the analysis of their growth and wood production, in varying sampling areas [6].

Alamo. This poplar is fairly widespread in the suburbs of Almaty. Mostly, it is used in one to two row plantings, along streets and highways, and in small groves on land that is generally unsuitable for agricultural purposes.

This tree has a wide ovate shaped crown, and low, whorled branching. The bark of the young trees is gray, whereas the older trees have dark bark with deep cracks. Early shoots are ribbed and smooth. Leaves are broadly ovate to triangular, with a length and width of approximately 7 to $12 \mathrm{~cm}$. This species is easily propagated by stem cuttings. It differs from others with its rapid growth, especially in the first years of its life.

According to our observations the Alamo poplar satisfactorily tolerates some soil salinity. Relative salt tolerance of Alamo was identified by [7], who found poplar of $8-10$ years of age growing in moderate salinity (Choride $-0.11 \%$; sulfate $-0.56 \%)$, with shallow groundwater $(1-$ $1.5 \mathrm{~m}$ ) and heavy soils. However, where there was chloride of $0.14 \%$, poplar trees of a similar age suffered leaf fall.

Growth and productivity of Alamo was studied in soils of the territory Karasay district of Almaty region. This poplar species, grown in slightly reduced moisture conditions, with periodic moistening from dripping water terraces, reached an average height of $19.1 \mathrm{~m}$ and a breast-height diameter of 13.6 $\mathrm{cm}$ by the age of 8 years. The sample trees were planted in a 10-row strip within a $2.5 \times 1.5 \mathrm{~m}$ plot. Soil was steam sterilized before planting. The tree survival rate after planting and at the time of the survey, was $90 \%$. The tree trunks numbered 2400 per hectare.

Regular weeding and watering were carried out for the first three years only. The under-canopy plant growth was absent. The canopy was leafy, though, because of pests, the leaves were deformed. Soil was a light chestnut color, had a medium clay loam texture, and was slightly moist. There was a strong soil profile evident. Overlaying the forest loam was the humus horizon, which reached $0.5 \mathrm{~m}$. Carbonates appeared in a layer at a depth of $100 \mathrm{~cm}$. Tree condition was good, with no sign of damage from fungi or plant pests. Shrinkage of lower branches (at about mid trunk height) was observed during planting. The results from analysis of the Alamo poplar, grown until the age of 8 years, in the study plot are given in table 1. 
Table 1. Results of growth analysis of sample Alamo poplar trees in Almaty suburbs

\begin{tabular}{|c|c|c|c|c|c|c|}
\hline $\begin{array}{c}\text { Age } \\
(\text { years })\end{array}$ & $\begin{array}{c}\text { Average } \\
\text { Height } \\
(\mathrm{m})\end{array}$ & $\begin{array}{c}\text { Average annual } \\
\text { height increment } \\
\text { since last reading } \\
(\mathrm{m})\end{array}$ & $\begin{array}{c}\text { Average } \\
\text { Diameter at } \\
\text { breast height } \\
(\mathrm{cm})\end{array}$ & $\begin{array}{c}\text { Average annual } \\
\text { diameter increment } \\
\text { since last reading } \\
(\mathrm{cm})\end{array}$ & $\begin{array}{c}\text { Average trunk } \\
\text { mass }\left(\mathrm{m}^{3}\right)\end{array}$ & $\begin{array}{c}\text { Average annual mass } \\
\text { increment since last } \\
\text { reading }\left(\mathrm{m}^{3}\right)\end{array}$ \\
\hline 2 & 3.3 & - & 2.0 & - & 0.0008 & start \\
\hline 4 & 8.2 & 2.45 & 6.6 & 2.30 & 0.0164 & 0.0076 \\
\hline 6 & 13.4 & 2.60 & 10.8 & 2.10 & 0.0595 & 0.0216 \\
\hline 8 (w/o bark) & 19.1 & 2.85 & 13.2 & 1.20 & 0.1110 & 0.0257 \\
\hline 8 (w/bark) & 19.1 & - & 13.6 & - & 0.1170 & - \\
\hline \multicolumn{7}{|c|}{ Source: Author } \\
\hline
\end{tabular}

Table 2. Growth of sample trees of Alamo poplar in the study of a 9-year planting

\begin{tabular}{|c|c|c|c|c|c|c|}
\hline Age (years) & $\begin{array}{c}\text { Average height } \\
(\mathrm{m})\end{array}$ & $\begin{array}{c}\text { Average annual } \\
\text { height increment } \\
\text { since last reading } \\
(\mathrm{m})\end{array}$ & $\begin{array}{c}\text { Average } \\
\text { diameter at } \\
\text { breast height } \\
(\mathrm{cm})\end{array}$ & $\begin{array}{c}\text { Average annual } \\
\text { diameter increment } \\
\text { since last reading } \\
(\mathrm{cm})\end{array}$ & $\begin{array}{c}\text { Average trunk } \\
\text { mass }\left(\mathrm{m}^{3}\right)\end{array}$ & $\begin{array}{c}\text { Average annual mass } \\
\text { increment since last } \\
\text { reading }\left(\mathrm{m}^{3}\right)\end{array}$ \\
\hline 2 & 3.1 & 2.2 & 1.85 & 0.0010 & 0.0114 & 0.0052 \\
\hline 4 & 7.3 & 2.10 & 5.9 & 2.40 & 0.0548 & 0.0217 \\
\hline 6 & 12.8 & 2.75 & 10.7 & 1.45 & 0.1428 & 0.0297 \\
\hline 9 (w/o bark) & 20.1 & 2.35 & 14.7 & - & 0.1540 & - \\
\hline 8 (w/bark) & 20.1 & - & 15.7 & & \\
\hline
\end{tabular}

Table 1 shows that the sample trees differed in the rate of growth in height with age. An annual height increment of $2.45 \mathrm{~m}$, on average, between 2 and 4 years, increased to 2.85 $\mathrm{m}$ between 6 and 8 years, indicating increasing growth rate in height with age.

Conversely, there was a decreasing trend for the annual increment of tree diameter. Although this rate of increase was relatively high up to the age of 6 years, it fell by $75 \%$ on average over the next two years. The timber stock would yield $280.8 \mathrm{~m} 3$ per hectare, based on an average trunk mass of 0.111 and a planting of 2400 trees per hectare.

A 9-year planting of Alamo poplar trees produced higher yield on meadow marsh with a strong alluvial layer. Gleization in the soil profile was indicated at a depth of 60 $\mathrm{cm}$, and groundwater was at a depth of $130 \mathrm{~cm}$.

The tree survival rate from the planting, at the time of the investigation, was $92 \%$. The number of tree trunks comprised 2831 per hectare. The shrinkage of some trees was evident during planting.

At the age of nine years, the sample trees had an average height of $20.1 \mathrm{~m}$, and an average breast-height diameter of $15.7 \mathrm{~cm}$.

Data of the sample trees, in terms of growth by trunk height, diameter and mass under modeled conditions are shown in Table 2.

The data listed in Table 2 show that the height of the sample trees increased in rate until six years of age. The annual height increment peaked between years 4 and 6 with an average of $2.75 \mathrm{~m}$ during that time. This fell to an average of $2.35 \mathrm{~m}$ per year thereafter, which was higher than the average annual growth rate in height overall (i.e. $2.23 \mathrm{~m}$ ).

The annual increment in diameter reached its maximum between years 4 and 6 , and then declined quite sharply thereafter to a level lower than the average over the whole period $(1.63 \mathrm{~cm})$. Based on the data, timber stock would yield $436 \mathrm{~m} 3$ per hectare, from an average trunk mass of $0.1540 \mathrm{~m} 3$ and a planting of 2831 trees per hectare.

The poplar, Alamo, has an exceptional rate of growth on alluvial-meadow soils with adequate moisture. To study the rate of growth and productivity of Alamo poplar grown on these soils, a sampling area involving an 8-row planting was set up in the grove near the floodplain terrace, Baum Almaty. Soil profiles showed a gleyed loamy horizon at a depth of 60 $\mathrm{cm}$, which was well moistened with an emergence of fresh groundwater at a depth of $150 \mathrm{~cm}$. Data from 183 poplar and willow SRC on 102 experimental plots located in the central-northern Italy, have shown that the presence of water proved to be a major factor in the establishment of energy plantations poplars and willows in the river valley. Possible changes in precipitation resulting from climate change could seriously affect the suitability of the SRC, as well as the choice of planting density can increase the yield of biomass in the first two years, especially in clones of black poplar [8].

Yearlings were planted in prepared plots of $3 \times 3 \mathrm{~m}$. In the first $2-3$ years, spaces between the rows of trees were used as gardens by the local people. The tree survival rate from the plantings, at the time of the survey, was $94 \%$. The number of tree trunks per hectare was 1044. Damage from infestations of fungi and plant pests was not observed. The general absence of large branches for almost the entire length of the tree trunks was noteworthy. At the age of 10 years the average height of a sample tree was $21.0 \mathrm{~m}$ and the breast-height diameter $25.1 \mathrm{~cm}$. 
Table 3. Growth of sample trees in the Alamo poplar 8-row study

\begin{tabular}{|c|c|c|c|c|c|c|}
\hline $\begin{array}{c}\text { Age } \\
(\text { years })\end{array}$ & $\begin{array}{c}\text { Average height } \\
(\mathrm{m})\end{array}$ & $\begin{array}{c}\text { Average annual } \\
\text { height increment } \\
\text { since last reading } \\
(\mathrm{m})\end{array}$ & $\begin{array}{c}\text { Average } \\
\text { diameter at } \\
\text { breast height } \\
(\mathrm{cm})\end{array}$ & $\begin{array}{c}\text { Average annual } \\
\text { increment since } \\
\text { last reading } \\
(\mathrm{cm})\end{array}$ & $\begin{array}{c}\text { Average trunk mass } \\
\left(\mathrm{m}^{3}\right)\end{array}$ & $\begin{array}{c}\text { Average annual } \\
\text { trunk mass } \\
\text { increase since last } \\
\text { reading }\left(\mathrm{m}^{3}\right)\end{array}$ \\
\hline 2 & 3.6 & 2.1 & & 0.0008 & \\
\hline 4 & 8.3 & 2.35 & 7.9 & 2.90 & 0.0140 & 0.0060 \\
\hline 6 & 13.5 & 2.60 & 13.6 & 2.85 & 0.0627 & 0.0243 \\
\hline 8 & 17.2 & 1.85 & 18.3 & 2.35 & 0.1614 & 0.0494 \\
\hline 10 (w/o bark) & 20.1 & 1.90 & 22.5 & 2.10 & 0.3155 & 0.0770 \\
\hline 10 (w/bark) & 20.1 & - & 25.1 & - & 0.3523 & - \\
\hline & & \multicolumn{2}{|c|}{ Source: Author } \\
\hline
\end{tabular}

Table 4. Growth of sample Alamo trees in plantations near Almaty

\begin{tabular}{|c|c|c|c|c|c|c|}
\hline Age (years) & $\begin{array}{c}\text { Average height } \\
(\mathrm{m})\end{array}$ & $\begin{array}{c}\text { Average annual } \\
\text { height increment } \\
\text { since last reading } \\
(\mathrm{m})\end{array}$ & $\begin{array}{c}\text { Diameter at breast } \\
\text { height }(\mathrm{cm})\end{array}$ & $\begin{array}{c}\text { Average annual } \\
\text { increment since last } \\
\text { reading }(\mathrm{cm})\end{array}$ & $\begin{array}{c}\text { Average trunk } \\
\text { mass }\left(\mathrm{m}^{3}\right)\end{array}$ & $\begin{array}{c}\text { Average annual } \\
\text { trunk mass } \\
\text { increment since } \\
\text { last reading }\left(\mathrm{m}^{3} .\right)\end{array}$ \\
\hline 2 & 3.7 & 2.2 & & 0.0014 & \\
\hline 4 & 8.1 & 2.20 & 7.2 & 2.50 & 0.0209 & 0.0097 \\
\hline 6 & 12.7 & 2.30 & 13.9 & 3.35 & 0.0773 & 0.0282 \\
\hline 8 & 17.8 & 2.55 & 16.5 & 1.30 & 0.1470 & 0.0348 \\
\hline 10 & 21.9 & 2.10 & 18.6 & 1.05 & 0.2299 & 0.0415 \\
\hline 12 & 24.6 & 1.35 & 20.3 & 0.85 & 0.3268 & 0.0485 \\
\hline 14 & 26.9 & 1.15 & 22.2 & 0.95 & 0.4222 & 0.0477 \\
\hline 16 (w/o bark) & 28.7 & 0.90 & 23.8 & 0.80 & 0.5135 & 0.0456 \\
\hline 16 (w/bark) & 28.7 & - & 24.8 & - & 0.5520 & - \\
\hline & & Source: Author & & \\
\hline
\end{tabular}

The data for trunk height, diameter, and mass of the sample trees are shown in Table 3. The data in Table 3 show that the Alamo sample trees developed, with a high rate of increase in height up to 6 years, and thereafter declined in this rate to levels slightly below the average overall (i.e. 2.01 $\mathrm{m})$.

A similar growth pattern is seen in the annual change in tree diameter (Table 3). As shown in table 3 the 6 years poplar Alamo has a height of 13.5 meters. In Belgium 6 year old crops poplar clones are the most productive clones and Hoogvorst Hazendans $(T \times D)$ which had an average diameter of 5.7 and $6.6 \mathrm{~cm}$ in maximum diameter of 12.6 and $11.5 \mathrm{~cm}$. [9].

The maximum annual increment in diameter occurred in the first 6 years. The rate of growth in diameter decreased thereafter, with an average of $2.1 \mathrm{~cm}$ recorded for the years 8 to 10 . Based on the 10 year results, a timber stock for a hectare would yield $367.8 \mathrm{~m} 3$, from an average trunk mass of $0.3523 \mathrm{~m} 3$ and 1044 trees.

The planting of Alamo poplar, grown near Almaty, yielded higher productivity than the other similar planting of this tree. Here, the soil was alluvial-meadow, and medium loamy with no signs of salinity. Groundwater was at a depth of $160 \mathrm{~cm}$, and a tree study plot measured $2.5 \times 2 \mathrm{~m}$.

Regular watering and weeding around tree trunks was performed for three years after planting. The trunks differed in surface area to volume ratio, and were relatively free of twigs. The tree survival rate from the planting, at time of survey, was $90 \%$. The number of tree trunks comprised 1300 per hectare. There were no external features that indicated infestation of trees by fungi or plant pests. However, the core of the sample trees that were felled indicated the presence of "butt rot", which is commonly found in trees of $7-8 \mathrm{~m}$ height. At the age of 16 years, the average height of the sample trees was $28.7 \mathrm{~m}$, and the breast-height diameter 24.8 $\mathrm{cm}$. Growth measurements of the sample trees by trunk height, diameter and mass are shown in Table 4.

The data presented in Table 4 show that the most intensive growth of these trees, in terms of height, occurred until year 10 , after which this growth fell sharply. Until year 10, the rate of height increase averaged $2.19 \mathrm{~m}$, but peaked at an average of $2.55 \mathrm{~m}$ between the years 6 and 8 . In the years that followed, the rate more than halved, with $0.9 \mathrm{~m}$ recorded as the average height increment between years $14-16$.

A similar pattern of growth rate was recorded for the trunk diameter. The greatest rate of increase in the diameter was observed prior to year 6 . Based on these data, the timber stock in the plantation per hectare would yield $993.6 \mathrm{~m}^{3}$, from the number of trees and a trunk mass of $0.5520 \mathrm{~m}^{3}$.

An analysis of the above data shows that the highest rates 
of Alamo growth were observed on alluvial meadow, with medium loamy and well-aerated soils, and a bedding of fresh groundwater at a depth of $150 \mathrm{~cm}$. Moreover, the rapid growth in this species that was observed early receded with maturity. This was also evident from the analysis of the sample trees in a third plot, where the Alamo poplar is grown on meadow-bog saz soils, and displayed lower growth rates. These soils become waterlogged from a relatively shallow depth to groundwater, annual flooding in spring and with having a heavy texture that limits soil aeration. These features negatively affect the growth of poplar.

On light-brown soils, the Alamo poplar grew rapidly in the first five years. However, in subsequent years, growth decreased because of insufficient irrigation and the presence of a thick carbonate horizon in the lower layers of the soil (at a depth of $70 \mathrm{~cm}$ ).

Poplar Algerian. This tree is spread throughout small groves, and in green areas of cities, towns and highways of Almaty and Zhambyl regions. It is a decorative and slim tree with a narrow pyramidal crown, a distinct and full tree trunk, and thin branches appressed to the trunk. The bark of young trees is smooth and greenish-gray in color. With age, the tree bark becomes dark with shallow cracks. Leaves are ovate-triangular to oblong-rhombic, with pointed tips. This poplar tolerates dry conditions, is photophilous, and propagates well from stem cuttings. However, the lack of moisture in early stages of its growth causes dieback, and susceptibility to pests and diseases.

The Algerian poplar was grown in a small grove in the Malovodnoe village of Almaty on gray-meadow soils, which are medium loamy with low salinity, overlaying forest type loam. Within 13 years, these reached an average height of $20.2 \mathrm{~m}$ with breast-height diameter of $13.8 \mathrm{~cm}$. Groundwater was at a depth of $140 \mathrm{~cm}$.

Yearlings were planted in an area $1.2 \times 1.2 \mathrm{~m}$. The plot was regularly weeded and watered during the first $3-4$ years.
The tree survival rate after planting, at the time of the survey, was $82 \%$. The number of tree trunks per hectare was 5740 . It should be noted that trunks had few branches. There was no tree damage from infestation of fungi or plant pests. The shrinkage of some trees was observed during planting. The measurements of growth of sample trees in trunk height, diameter and mass are shown in Table 5 .

The data in Table 5 show that the most rapid growth period for height in these trees occurred between years 6 and 8. The annual increase in height was more than $2 \mathrm{~m}$ on average during this time. Thereafter, the growth in height decreased markedly, falling to $0.8 \mathrm{~m}$ between year 12 and 13 on average, which was almost half the average rate of increase $(1.55 \mathrm{~m})$ over the 13 years.

The annual increase in diameter reached a maximum of $2.25 \mathrm{~m}$ between $4-6$ years. Thereafter it declined sharply to a rate lower than the average rate for the 13 years $(1.00 \mathrm{~cm})$. The timber stock per hectare was $715.2 \mathrm{~m}^{3}$, based on a stand of 5740 trees and a $0.1246 \mathrm{~m}^{3}$ average trunk mass. The next sampling area involved a two-row strip of Algerian poplar, along the highway of Almaty Shelek. The soil was gray-meadow, which is medium loamy with low salinity. Groundwater was at a depth of $3.5 \mathrm{~m}$. Planting involved one-year-old seedlings in a plot, prepared with depressions in shallow ditches. The plot was continuously watered during the first 5-6 years. In subsequent years, irrigation was reduced during the growing season. The size of the study plot was $2.5 \times 2.0 \mathrm{~m}$. The tree survival rate was $78 \%$. There were 780 tree trunks per kilometer in two-row plantings. Damage from infestations of fungi or plant pests was not observed. Design of poplar clone plantation in southern Sweden $2.5 \mathrm{~m}$ $\times 2.5 \mathrm{~m}$, in Belgium 17 clones were planted in a double-row design with alternating inter-row distances of 0.75 and $1,5 \mathrm{~m}$, and a spacing of $0,9 \mathrm{~m}$ between cuttings within the rows. Seven poplar (Populus nigra) plantations in western Iran planted with $1 \times 1 \mathrm{~m}$ and $2 \times 2 \mathrm{~m}$ planting intervals [10].

Table 5. Growth measurements of sample trees in terms of trunk height, diameter and mass for the poplar, Algerian

\begin{tabular}{|c|c|c|c|c|c|c|}
\hline $\begin{array}{c}\text { Age } \\
\text { (years) }\end{array}$ & $\begin{array}{c}\text { Average height } \\
(\mathrm{m})\end{array}$ & $\begin{array}{c}\text { Average annual } \\
\text { height increment } \\
\text { since last reading } \\
(\mathrm{m})\end{array}$ & $\begin{array}{c}\text { Diameter at breast } \\
\text { height }(\mathrm{cm})\end{array}$ & $\begin{array}{c}\text { Average annual } \\
\text { increment since } \\
\text { last reading }(\mathrm{cm})\end{array}$ & $\begin{array}{c}\text { Average trunk } \\
\text { mass }\left(\mathrm{m}^{3}\right)\end{array}$ & $\begin{array}{c}\text { Average annual } \\
\text { trunk mass } \\
\text { increment since last } \\
\text { reading }\left(\mathrm{m}^{3}\right)\end{array}$ \\
\hline 2 & 2.3 & 1.3 & & 0.0003 & \\
\hline 4 & 6.1 & 1.90 & 3.3 & 1.00 & 0.0039 & 0.0018 \\
\hline 6 & 10.3 & 2.10 & 7.8 & 2.25 & 0.0237 & 0.0099 \\
\hline 8 & 14.6 & 2.15 & 9.9 & 1.05 & 0.1478 & 0.0120 \\
\hline 10 & 17.3 & 1.35 & 11.5 & 0.85 & 0.0748 & 0.0135 \\
\hline 12 & 19.4 & 1.05 & 12.8 & 0.65 & 0.1049 & 0.0150 \\
\hline 13 (w/o bark) & 20.2 & 0.80 & 13.1 & 0.30 & 0.1145 & 0.0096 \\
\hline 13 (w/bark) & 20.2 & - & 13.8 & - & 0.1246 & \\
\hline & & \multicolumn{7}{|l}{ Source: Author } \\
\hline
\end{tabular}


Table 6. Growth of sample poplar trees of Algerian, grown along the highway in Almaty-Shelek

\begin{tabular}{|c|c|c|c|c|c|c|}
\hline Age (years) & $\begin{array}{c}\text { Average height } \\
(\mathrm{m})\end{array}$ & $\begin{array}{c}\text { Average annual } \\
\text { height increment } \\
\text { from last reading } \\
(\mathrm{m})\end{array}$ & $\begin{array}{c}\text { Diameter at } \\
\text { breast height } \\
(\mathrm{cm})\end{array}$ & $\begin{array}{c}\text { Average annual } \\
\text { increment from } \\
\text { last reading }(\mathrm{cm})\end{array}$ & $\begin{array}{c}\text { Average trunk } \\
\text { mass }\left(\mathrm{m}^{3}\right)\end{array}$ & $\begin{array}{c}\text { Average annual trunk } \\
\text { mass increment from } \\
\text { last reading }\left(\mathrm{m}^{3}\right)\end{array}$ \\
\hline 2 & 2.2 & 1.2 & 0.0002 & 0.0019 & 0.0008 \\
\hline 4 & 5.0 & 1.65 & 4.4 & 1.10 & 0.0068 & 0.0025 \\
\hline 6 & 8.3 & 1.70 & 6.5 & 1.05 & 0.0120 & 0.0026 \\
\hline 8 & 11.7 & 1.05 & 9.8 & 1.65 & 0.0275 & 0.0077 \\
\hline 10 & 13.8 & 0.55 & 13.7 & 1.95 & 0.628 & 0.0176 \\
\hline 12 & 14.9 & 0.50 & 16.5 & 1.40 & 0.0144 & 0.0208 \\
\hline 14 & 15.9 & 0.25 & 20.8 & 1.00 & 0.2080 & 0.0270 \\
\hline 20 (w/o bark) & 17.6 & 0.30 & 22.4 & 0.80 & 0.2540 & 0.0230 \\
\hline 20 (w/bark) & 17.6 & - & 23.8 & - & 0.2801 & - \\
\hline
\end{tabular}

By the age of 20 years, the average tree height was $17.6 \mathrm{~m}$, and the diameter at breast height was $23.8 \mathrm{~cm}$. The measurements pertaining to growth of the sample trees in terms of trunk height, diameter and mass are shown in Table 6.

Due to the limited distribution of the poplar, Algerian, there was little opportunities to study its growth and productivity under varying soil conditions. An analysis of sample trees in study plots on gray meadow soils with low salinity showed that this poplar, like Alamo, displays rigorous growth. The poplar, Algerian, has smooth trunks with minor tapering and is a species that could be used more widespread, especially as a plantation specimen.

Poplar Bolle. In the conditions of Southeastern Kazakhstan, the Bolle poplar is the most common white poplar. Due to its high decorative crown shape, it is found predominantly in single or alley plantings, along the streets of cities and towns. Its trunk is straight with minor tapering; bark is gray-olive-green, smooth; and crown is widely pyramidal. The leaves are large, leathery, 5-7 lobed, and white-tomentose underneath. It can be satisfactorily propagated from stem cuttings. Compared with other species of poplar, this species is the most resistant to infestations of pests or plant diseases.

The tree has an average demand for soil moisture and tolerates soil salinity. According to Usmanov [11] the poplar Bolle, reaches an average height of $20.2 \mathrm{~m}$ within 18 years growth on strongly saline gray soil (solid residue $1.35 \%$, chloride $0.052 \%$, and sulfate $0.503 \%$ ). Nemtsova [12] recommends this type of poplar, is planted, in the southern regions of Kazakhstan, where these exist saline soils with dense residue $(1.851-2.005 \%)$, chloride of $0.034-0.580 \%$ and sulfate characterized by rapid growth and high production.

The main disadvantage of this type of poplar is that it has a weak resistance to frost, and this limits its advance in northern regions of Kazakhstan. According to our observations, even in the region of Taldykorgan (Sarkand, Uch -Aral, Dzerzhinsk), almost the entire planting of the poplar, Bolle, suffers from frost crack. Three test areas were set up to study the growth and productivity of this species of poplar.

The sampling area was situated in a tract of "Dzharkantskoe" of the Ili Panfilov forestry. Soil was graymeadow, and loamy with low salt content. In the soil profile, salt appeared to a depth of $40 \mathrm{~cm}$ in the form of specks. Groundwater was at a depth of $2.5-3 \mathrm{~m}$.

Yearlings were planted in soil prepared by shovel in an area $2.0 \times 1.5 \mathrm{~m}$. The plot was regularly watered for the first 5 years. The tree survival rate after planting, at time of survey, was $86 \%$. Tree trunks numbered 2866 per hectare. By the age of 11 , the average height of the trees in the plantation was $14.5 \mathrm{~m}$, and the diameter at breast height was $17 \mathrm{~cm}$. Growth of sample trees in terms of trunk height, diameter and mass for the study area is shown in Table 7. 
Table 7. Growth and productivity of the poplar, Bolle in a tract of "Dzharkantskoe" of the Ili Panfilov forestry

\begin{tabular}{|c|c|c|c|c|c|c|}
\hline $\begin{array}{c}\text { Age } \\
\text { (years) }\end{array}$ & $\begin{array}{c}\text { Average } \\
\text { height }(\mathrm{m})\end{array}$ & $\begin{array}{c}\text { Average annual } \\
\text { height increment } \\
\text { since last reading } \\
(\mathrm{m})\end{array}$ & $\begin{array}{c}\text { Diameter at } \\
\text { breast height } \\
(\mathrm{cm})\end{array}$ & $\begin{array}{c}\text { Average annual } \\
\text { increment since } \\
\text { last reading }(\mathrm{cm})\end{array}$ & $\begin{array}{c}\text { Average trunk } \\
\text { mass }\left(\mathrm{m}^{3}\right)\end{array}$ & $\begin{array}{c}\text { Average annual } \\
\text { trunk mass } \\
\text { increment since } \\
\text { last reading }\left(\mathrm{m}^{3}\right)\end{array}$ \\
\hline 2 & 2.6 & 1.8 & & 0.0005 & \\
\hline 4 & 5.9 & 1.65 & 4.6 & 1.40 & 0.0059 & 0.0027 \\
\hline 6 & 9.1 & 1.60 & 8.5 & 1.95 & 0.02220 & 0.0082 \\
\hline 8 & 11.6 & 1.25 & 12.6 & 2.05 & 0.0588 & 0.0183 \\
\hline 10 & 13.7 & 1.05 & 15.4 & 1.40 & 0.0980 & 0.0196 \\
\hline $11(\mathrm{w} / \mathrm{o}$ bark $)$ & 14.5 & 0.80 & 16.5 & 1.10 & 0.1095 & 0.0115 \\
\hline $11(\mathrm{w} / \mathrm{bark})$ & 14.5 & - & 17.0 & - & 0.0232 & - \\
\hline & & \multicolumn{5}{c}{ Source: Author } \\
\hline
\end{tabular}

Table 8. Growth of sample trees by height, diameter and volume of Bolle poplar, grown in a two -row band in a territory garden, protected by fruit and berry sorting and experimental plot in Panfilov district

\begin{tabular}{|c|c|c|c|c|c|c|}
\hline Age (years) & $\begin{array}{c}\text { Average height } \\
(\mathrm{m})\end{array}$ & $\begin{array}{c}\text { Average annual } \\
\text { height increment } \\
\text { from last reading } \\
(\mathrm{m})\end{array}$ & $\begin{array}{c}\text { Diameter at breast } \\
\text { height }(\mathrm{cm})\end{array}$ & $\begin{array}{c}\text { Average annual } \\
\text { increment from } \\
\text { last reading }(\mathrm{cm})\end{array}$ & $\begin{array}{c}\text { Average trunk } \\
\text { mass }\left(\mathrm{m}^{3}\right)\end{array}$ & $\begin{array}{c}\text { Average annual } \\
\text { trunk mass } \\
\text { increment from last } \\
\text { reading }\left(\mathrm{m}^{3}\right)\end{array}$ \\
\hline 2 & 2.5 & 2.0 & & 0.0026 & \\
\hline 4 & 5.9 & 1.70 & 6.0 & 2.00 & 0.0146 & 0.0065 \\
\hline 6 & 10.1 & 2.10 & 10.1 & 2.05 & 0.0456 & 0.0155 \\
\hline 8 & 14.2 & 2.05 & 13.6 & 1.75 & 0.1029 & 0.0286 \\
\hline 10 (w/o bark) & 17.0 & 1.40 & 15.9 & 1.15 & 0.01725 & 0.0348 \\
\hline 10 (w/bark) & 17.0 & - & 16.3 & - & 0.1855 & \\
\hline & \multicolumn{7}{|l}{ Source: Author } \\
\hline
\end{tabular}

From Table 7, it is seen that the most rapid growth in height occurred between years 2 and 4 with an average rate of $1.6 \mathrm{~m}$. In subsequent years, this rate declined gradually and by the time the trees were felled, the rate had decreased to $0.8 \mathrm{~m}$ on average, which was half that observed in the first five years. A similar pattern was observed in the annual increment in trunk diameter. Timber stock at 11 years per hectare is estimated as $353.1 \mathrm{~m}^{3}$, from an average trunk mass of 0.1232 and 2866 trees. In Mediterranean conditions, the density to create plantations varied between 6666 and 33333 seats per 1 hectare, with the final yield of biomass varied from $185 \mathrm{mg} \mathrm{dm}$ ha-1 [13].

Next, Bolle poplars were planted in a two-row band in a territory garden, protected by a sorting experimental plot of Panfilov district. In 10 years, these reached an average height of $17 \mathrm{~m}$ and a diameter at breast height of $16.3 \mathrm{~cm}$. Soil was gray-meadow, with medium loam, no signs of salinity and a thick humus horizon.

Watering was carried out regularly through irrigating ditches along the rows. The plot was $2 \times 2 \mathrm{~m}$. The tree survival rate after the planting, at time of survey, was $100 \%$. The number of tree trunks per kilometer of two-row plantings was 1000 . Growth of the sample trees in terms of trunk height, diameter and mass are given in Table 8 .

The data shown in Table 8 indicates rigorous tree growth in terms of both height and diameter. The annual height increment between years 4 and 8 was just over $2 \mathrm{~m}$ on average, while in the last 2 years this decreased to $1.4 \mathrm{~m}$ on average. A similar pattern is observed with respect to growth diameter. Timber stock for a kilometer of a two-row planting is estimated at $185.5 \mathrm{~m}^{3}$ [14] , based on 1000 trees and a trunk mass of $0.1855 \mathrm{~m}^{3}$.

In addition, the Bolle poplar displayed good growth and high performance when grown in a two-row planting scenario within a protected garden strip in the territory of Sarkand district. This poplar reached an average height of $19.3 \mathrm{~m}$ and a breast-height diameter of $22.8 \mathrm{~cm}$ within 15 years after planting on dark chestnut, medium loam soil in an area $2 \times 2 \mathrm{~m}$. The tree survival rate from the planting, at time of survey, was $84 \%$. Individual trees were damaged by frost-crack after reaching $3-4 \mathrm{~m}$ in trunk height. Damage from infestations of fungi and plant pests was not marked. The number of tree trunks per kilometer of two- row plantings was 840. Growth measurements of sample trees taken from the plot are shown in Table 9. 
Table 9. Growth measurements of sample trees of poplar Bolle, grown in two-row gardens protected by a strip along the ditch in the Sarkand district

\begin{tabular}{|c|c|c|c|c|c|c|}
\hline Age (years) & $\begin{array}{c}\text { Average height } \\
(\mathrm{m})\end{array}$ & $\begin{array}{c}\text { Average annual } \\
\text { height increment } \\
\text { since last reading } \\
(\mathrm{m})\end{array}$ & $\begin{array}{c}\text { Diameter at breast } \\
\text { height }(\mathrm{cm})\end{array}$ & $\begin{array}{c}\text { Average annual } \\
\text { increment since } \\
\text { last reading }(\mathrm{cm})\end{array}$ & $\begin{array}{c}\text { Average trunk } \\
\text { mass }\left(\mathrm{m}^{3}\right)\end{array}$ & $\begin{array}{c}\text { Average annual } \\
\text { trunk mass } \\
\text { increment since last } \\
\text { reading }\left(\mathrm{m}^{3}\right)\end{array}$ \\
\hline 2 & 2.2 & 1.8 & & 0.0010 & \\
\hline 4 & 5.6 & 1.70 & 4.8 & 1.50 & 0.0052 & 0.0021 \\
\hline 6 & 9.5 & 1.95 & 8.6 & 1.90 & 0.0192 & 0.0070 \\
\hline 8 & 12.3 & 1.40 & 12.8 & 2.10 & 0.0676 & 0.0242 \\
\hline 10 & 14.5 & 1.10 & 16.0 & 1.60 & 0.1363 & 0.0343 \\
\hline 12 & 17.8 & 1.00 & 19.1 & 1.55 & 0.1986 & 0.0312 \\
\hline 14 & 18.9 & 0.55 & 21.0 & 0.95 & 0.2444 & 0.0229 \\
\hline 16 & 16.5 & 0.40 & 18.8 & 0.50 & 0.1539 & 0.0174 \\
\hline 18 & 17.0 & 0.25 & 20.8 & 1.00 & 0.2080 & 0.0270 \\
\hline 15 (w/o bark) & 19.3 & 0.30 & 21.5 & 0.80 & 0.2618 & 0.0230 \\
\hline 15 (w/bark) & 19.3 & - & 22.8 & - & 0.2832 & - \\
\hline & & & Source: Author & & & \\
\hline
\end{tabular}

Table 9 shows that these poplar Bolle trees developed well in height and diameter up to 10 years of age, with rates of increase in height between 1.10 and $1.95 \mathrm{~m}$, and in diameter between 1.55 and $2.10 \mathrm{~cm}$ on average during this time. These rates decreased thereafter, particularly for height, with a minimum rate of increase of $0.25 \mathrm{~m}$ on average observed between the years 16 and 18 . Based on the results, the timber stock per kilometer of two-row plantings would yield 237.9 $\mathrm{m} 3$, from 840 trees and a trunk mass of 0.2832 at year 15 .

\section{Conclusions}

An analysis of the growth of the above sample trees shows that the poplar, Bolle, grown under favorable soil conditions and with regular watering is characterized by vigorous growth with the average annual height increment at some stages reaching $2 \mathrm{~m}$, and yielding a much greater volume for timber stock.

On the basis of our research into the study of growth and productivity of poplar species, we conclude the following:

- The most common species, deltoid, Algerian, and Bolle, are widely spread throughout Southeastern Kazakhstan because of the extensive planting of greenery;

- Favorable soil and climatic conditions allow the growth of high-yield poplar plantations. The main factors that ensure high productivity of poplar plantations are the soil conditions of fertility, good aeration and adequate moisture;

- Maximum poplars' rate of gain for height occurs between the years 5 and 10 and for diameter between the years 4 and 9 , on average, after planting. After reaching optimal growth in height and diameter, its rate of growth begins to decline gradually, but plummets 14 to- 16 years after planting;

- High productivity of poplar plantations is achieved in plots of $2.5-3 \times 1.5-2 \mathrm{~m}$ with 20003000 trees per hectare. The creation of dense stands of $5000-7000$ trees per hectare leads to rapid growth of trees in height, but quite early growth reduction in terms of diameter.

\section{REFERENCES}

[1] Tsarev A.P. Cultivar division of poplar. Voronezh, Publishing house of Voronezh State University,1985. pp.7-13.

[2] Besszetnov, P. P. Poplar ((culture and breeding), Alma-Ata, 1969156

[3] Melekhov I.S. The plantation is located near the factory. Timber industry. 1981,

[4] Sarsekov D. Forestry Technology watering in the south-east of Kazakhstan. Monograph, Lambert Academic Publishing, Germany, 2012, 120.

[5] Treshchevskiy I.V., Ivanov F.E., Pankow Y.V. Forest reclamation of lands disturbed by mining technical works. L., 1978,42

[6] Besszetnov, P. P. Gibridnyje topolya i ich rol v povyszenii produktivnosti lesov Kazachstana [Gibridnyj Topolya and their role in the advancement in productivity of forests Kazachstana]. Issledovaniya, 4, 25-28, 1999

[7] Popov, I. T. (1961). Physical and chemical properties of Siberian larch of Saura ridge. Works of Kazakh Scientific Research Institute of Forestry, 3, 229-236.

[8] Sara Bergante, Gianni Facciotto, Gianfranco Minotta: 
Identification of the main site factors and management intensity affecting the establishment of Short-Rotation-Coppices (SRC) in Northern Italy through stepwise regression analysis. Central European Journal of Biology August 2010,Volume 5,Issue 4,pp 522-530

[9] Freckleton R.P and Watkinson A.R. Asymmetric competition between plant species. Functional Ecology 2001. 15, pp 615623

[10] Rebecka Mc Carthy, Per Magnus Ekö,Lars Rytter. Reliability of stump sprouting as a regeneration method for poplars: clonal behavior in survival, sprout straightness and growth. Silva Fennica (2014) vol. 48 no. 3 article id 1126.9 p.

[11] Usmanov, G. R. (1967). Variety testing and implementation of promising species of poplars in protective forest plantations. Works of Kazakh Scientific Research Institute of Forestry, 6,
235-237.

[12] Nemtsova, R. M. (1959). About the development of root systems of trees and shrubs in saline soils. Works of Kazakh Scientific research Institute of Forestry, 2, 108-122.

[13] Oliveira N., Sixto H., Cañellas I., Rodríguez-Soalleiro R., Pérez-Cruzado C. Productivity model and reference diagram for short rotation biomass crops of poplar grown in Mediterranean environments. Elsevier, biomass and bioenergy, 72, (2015) p 309-320.

[14] Pliura, A., Suchockas, V., Sarsekova, D., \& Gudynaite, V. (2014). Genotypic variation and heritability of growth and adaptive traits, and adaptation of young poplar hybrids at northern margins of natural distribution of Populus nigra in Europe. Biomass and Bioenergy, 70(0), p 513-529. doi: http://dx.doi.org/10.1016/j.biombioe.2014.09.011 